\title{
Addressing God in European languages: Different meanings, different cultural attitudes
}

\author{
Anna Wierzbicka \\ Australian National University \\ Canberra, Australia
}

\begin{abstract}
All European languages have a word for God, and this word means exactly the same in all of them. However, speakers of different European languages tend to relate to God in different ways. Each group has its own characteristic ways of addressing God, encoded in certain words, phrases and grammatical forms, which both reflect and shape the speakers' habitual ways of thinking about God and relating to God. Often, they also reflect some other aspects of their cultural memory and historical experience. In this paper I will compare the meanings of the vocative expressions used for addressing God in several European languages, including "Gospodi" in Russian, "O God" in English, "Mon Dieu" in French, "Herr" in German, and "Boże" in Polish. But to compare those meanings, we need a common measure. I believe such a common measure is available in the "NSM" framework, from Natural Semantic Metalanguage (see e.g. Goddard and Wierzbicka, 2014; Wierzbicka 2014a and 2018a; Gladkova and Larina 2018a, b).

The data is taken mainly from well-known works of literature, such as Lev Tolstoy's Anna Karenina and Boris Pasternak's poem "V bol'nice" ("In Hospital”) for Russian, Charles Peguy's Le mystère de la charité de Jeanne d'Arc and its English translation by Julien Green for French and English, and Dietrich Bonhoeffer's prison poems and Heinrich Böll's novel Billard um halbzehn for German. The results have shown that each European language offers its users a range of options for addressing God. Some of these options are shared, others appear to be unique to the language. All are underpinned by broader historical phenomena. The exact nature of all these links remains to be investigated.
\end{abstract}

Keywords: God, terms of address, NSM Semantics, Natural Semantic Metalanguage, addressing God in different languages, Christianity

\section{For citation:}

Wierzbicka, Anna. 2020. Addressing God in European languages: different meanings, different cultural attitudes. Russian Journal of Linguistics 24 (2). 259-293. DOI: 10.22363/2687-00882020-24-2-259-293 
Научная статья

\title{
Обращение к Богу в европейских языках: различные значения, различные культурные установки
}

\author{
Анна Вежбицкая \\ Австралийский национальный университет \\ Канберра, Астралия
}

\begin{abstract}
Аннотация
Во всех европейских языках есть слово для обозначения Бога, и это слово имеет одинаковое значение. Тем не менее, носители разных европейских языков, как правило, обращаются к Богу по-разному. У каждой группы есть свои характерные способы обращения к Богу, закодированные в определенных словах, фразах и грамматических формах, которые отражают и формируют привычные способы мышления о Боге и отношение к Богу. Часто они также отражают некоторые другие аспекты культурной памяти и исторического опыта.Статья посвящена сопоставлению значений вокативных слов и фраз, используемых для обращения к Богу на нескольких европейских языках, включая «Господи» на русском языке, «O God» на английском языке, «Mon Dieu» на французском языке, «Herr» на немецком и «Воże» на польском. Для сравнения этих значений необходимо единое измерение. Есть все основания полагать, что в качестве такого измерения может быть использован Естественный Семантическмй Метаязык (NSM) (см., например, Goddard and Wierzbicka, 2014; Wierzbicka 2014а и 2018a; Gladkova and Larina 2018a, b и др.). Материал для исследования был взят в основном из известных литературных произведений, таких как роман Льва Толстого «Анна Каренина» и стихотворение Бориса Пастернака «В больнице» для русского языка, «Мистерия о милосердии Жанны Д’Арк» Шарля Пеги и ее английский перевод Жюльена Грина для французского и английского языков, тюремные стихи Дитриха Бонхеффера и роман Генриха Белля «Бильярд в половине десятого» для немецкого языка. Результаты показали, что каждый европейский язык предлагает своим пользователям различные варианты обращения к Богу. Некоторые из них являются общими, другие представляются уникальными для того или иного языка. Все они обусловлены более широким историческим контекстом, конкретное влияние которого еще предстоит изучить.

Ключевые слова: Бог, формы обращения, семантика языковых примитивов, Естественный Семантический Метаязык, обращение к Богу на различных языках, христианство
\end{abstract}

\section{Для цитирования:}

Wierzbicka, Anna. 2020. Addressing God in European languages: different meanings, different cultural attitudes. Russian Journal of Linguistics 24 (2). 259-293. DOI: 10.22363/2687-00882020-24-2-259-293

\section{Introduction:}

\section{Comparing meanings requires a common measure}

All European languages have a word for God, and this word means exactly the same in all of them. But when it comes to addressing God, the situation is very different. Speakers of different European languages tend to relate to God in different ways. Each group has its own characteristic ways of addressing God, encoded in certain words, phrases and grammatical forms. These words, phrases, 
and grammatical forms both reflect and shape the speakers' habitual way of thinking about God and relating to God. Often, they also reflect some other aspects of their cultural memory and historical experience.

Talking to God is a large part of Christianity. According to the Christian view (and indeed, to the biblical view), God created people on earth with the expectation that he will speak to them, and that they will recognize him as God, and speak to him. John Paul II (2002) describes prayer as "the breath of Christian life" (p. 9) and states that "the universal Church of Christ, and hence every particular church, exists for prayer." (p. 3, emphasis in the original) But to speak to God, or to pray, people need some way to address God. As Europeans started to talk to the Christian God in European languages, some ways of addressing God shared by speakers of a given language had to develop and establish themselves. One suspects that the Psalms, which were in the past, and still are, part and parcel of Christianity, were an important school of prayer in all European countries. But the psalms first came to Europe through languages which had a vocative case: thee and kyrie in Greek, Deus and Domine in Latin. ${ }^{1}$ In contrast to Greek and Latin, modern western European languages had no vocative case, yet the problem of addressing God had to be solved somehow, and each language solved it in its own way - as we can see looking at the different European translations of the psalms. As I will discuss in more detail later, English solved the problem chiefly by rendering the vocative "Deus" as "O God", and the vocative "Domine" as "O Lord" — and this tradition persists to this day, although there have also been some changes.

Other European languages adopted, in time, other solutions - apparently better suited to the cultures of their speakers, and also subject to change. Each solution, however, involves a particular meaning, and reflects a particular conceptual stand. If we can decode the meanings embedded in different words and phrases which are habitually used in different European countries for addressing God, we can find out something significant about different cultural traditions.

But to compare those meanings, we need a common measure. This applies to Christian faith and prayer as much as to any other domain ${ }^{2}$. I believe such a common measure is available in the set of 65 human concepts (semantic primes) shared, as evidence suggests, by most, if not all, human languages. This common measure is the outcome of decades of cross-linguistic investigations conducted by many scholars within the "NSM" framework, from Natural Semantic Metalanguage. (See e.g. Wierzbicka 1996, 2014a and b, Goddard 2011 [1998], Goddard (ed.) 2018, Goddard and Wierzbicka 2014, eds. 2002, Peeters ed. 2006).

In addition to the sixty five concepts included in Table 1, NSM-based research has also shown that there are many complex concepts - definable in terms of the sixty five - which also appear to be shared by most, if not all, human languages. In NSM theory, such concepts are called "universal semantic molecules". According to NSM-based cross-linguistic research, these include concepts like 'men', 'women', 'children', 'mother', 'father', 'hands', and a few dozen more. Crucially for my current topic, they include the social molecule 'us'. 
Semantic primes (English exponents) (Goddard \& Wierzbicka 2014)

\begin{tabular}{|l|r|}
\hline I, YOU, SOMEONE, SOMETHING THING, PEOPLE, BODY & substantives \\
\hline KINDS, PARTS & relational substantives \\
\hline THIS, THE SAME, OTHER ELSE & determiners \\
\hline ONE, TWO, SOME, ALL, MUCH MANY, LITTLE FEW & quantifiers \\
\hline GOOD, BAD & evaluators \\
\hline BIG, SMALL & mental predicates \\
\hline KNOW, THINK, WANT, DON'T WANT, FEEL, SEE, HEAR & speech \\
\hline SAY, WORDS, TRUE & actions, events, movement \\
\hline DO, HAPPEN, MOVE & location, existence, specification \\
\hline BE (SOMEWHERE), THERE IS, BE & possession \\
(SOMEONE/SOMETHING) & life and death \\
\hline (IS) MINE & time \\
\hline LIVE LIVING, DIE & place \\
\hline WHEN TIME, NOW, BEFORE, AFTER, A LONG TIME, & A SHORT TIME, FOR SOME TIME, MOMENT \\
\hline WHERE PLACE, HERE, ABOVE, BELOW, FAR, NEAR, & logical concepts \\
SIDE, INSIDE, TOUCH & augmentor, intensifier \\
\hline NOT, MAYBE, CAN, BECAUSE, IF & similarity \\
\hline VERY, MORE & \\
\hline LIKE &
\end{tabular}

Notes: - Exponents of primes can be polysemous, i.e. they can have other, additional meanings.

- Exponents of primes may be words, bound morphemes, or phrasemes. - They can be formally, i.e., morphologically, complex. • They can have combinatorial variants or allolexes (indicated with ).

- Each prime has well-specified syntactic (combinatorial) properties.

In addition to universal semantic molecules, there are also molecules shared by some - or many - languages, but not by all. A non-universal molecule which will play an important role in this paper is "God". An abbreviated definition of this concept built out of primes may look like this:

\section{God}

There is someone not like people.

This someone is someone above people.

This someone is above everything.

This someone is now, always was, always will be.

This someone is everywhere.

There is no one else like this someone.

God is this someone.

People can't see God.

At the same time, people can know some things about God.

They can know that God is good.

They can know some other things about God.

God wants people to know these things.

(For my earlier work on Christianity seen through the prism of NSM semantics, see

Wierzbicka 2001, 2017, 2018a, b, and c, 2019.) 
In this paper, I will compare some salient ways of addressing God in Russian, French, German, English, and Polish. Needless to say, I am not going to try to be exhaustive. Nor will I be able to discuss the use of exclamatory phrases such as "Oh my God" or "Good Lord!" (used not for addressing God, but for expressing an emotion), although I believe they provide some support for the analysis developed in the present paper. For earlier NSM-based work where such exclamatory phrases were discussed, see e.g. Goddard (2013), Wierzbicka (1992, 2003). For a largescale NSM-based study of the semantics of terms of address, see Farese (2018). See also Wierzbicka 2016a.

\section{Russian: addressing God with "Gospodi!"}

Judging by the evidence of Russian literature, for Russians, the most common and most characteristic conceptual tool for thinking about God is the word "Gospod", and the most distinctly Russian verbal tool for addressing God is the old vocative form "Gospodi".

Roughly, "Gospod" means "God seen as the Lord of the universe". I will give a more precise semantic analysis of this uniquely Russian concept shortly, but first I will illustrate its use with a few extracts from Tolstoy's novel Anna Karenina in an English translation, where "Gospodi" is replaced by either "Lord" or "God".

The extracts refer to a dramatic situation when the heroine Kitty is giving birth (for the first time) and her husband Kostia Levin is terrified and hearing Kitty's screams (often minimized in the English translation) is convinced that she is going to die.

(1)

He was already on his way through the drawing-room when suddenly a piteous moan, that lasted only a moment, reached him from the bedroom. He stopped and for a moment could not understand it.

'Yes, it was she,' he said and, clasping his head with his hands, he ran downstairs.

'Lord have mercy! Pardon and help us!' [Gospodi, pomiluy! Prosti, pomogi!] he repeated the words that suddenly and unexpectedly sprang to his lips. And he, an unbeliever, repeated those words not with his lips only. At that instant he knew that neither his doubts nor the impossibility of believing with his reason - of which he was conscious - at all prevented his appealing to God. It all flew off like dust. To whom should he appeal, if not to Him in whose hand he felt himself, his soul, and his love, to be? (Translated by Louise and Aylmer Maude)

In Russian, the key phrase here is "Gospodi, pomiluj! Prosti, pomogi!" There is no "and" and no "us" in the Russian version, and the tone is far more immediate and dramatic than in the English translation. When Levin sees the midwife coming, he says to her anxiously: 'God have mercy and help us!' (in Russian, 'Gospodi, pomiluj i pomogi"). Then the translators switch to "Lord" once more, apparently hoping that the alternation of "God" and "Lord" will allow them to better capture 
something of the unique semantic content, and flavour, of "Gospodi": "Lord, pardon and help us!', he kept repeating incessantly to himself, appealing to God, in spite of a long period of apparently complete estrangement, just as trustingly and simply as in the days of childhood and youth." When he was talking next door to the doctor, or to Kitty's relatives, Levin momentarily forgot what was happening, but

(2)

...in her presence, by her pillow, where his heart was ready to burst with pity and yet did not burst, and there he prayed unceasingly to God. (...) every time, on hearing the scream, he jumped up and ran to justify himself, but recollected on the way that he was not to blame and that he longed to protect and help her. But when, looking at her, he again saw that to help was impossible, he was seized with horror and said, 'Lord, pardon and help us!' (...) sometimes (...) he blamed God; but the thought of God made him at once pray for forgiveness and mercy. (translated by L. and A. Maude)

Translations of Anna Karenina into languages other than English are similarly unable to cope with the semantics of "Gospodi". For example, the Polish translation by the well-known poet Kazimiera Iłłakowicz uses, throughout, the vocative of the word "Bóg" (God), that is, "Boże", whereas the French translation (Paris: Nelson, Éditeurs) replaces one instance of "Gospodi" with "Seigneur", one with "Dieu", and reduces the remaining three to a descriptive sentence: "son âme criait vers Dieu", that is, "his soul was crying towards God".

I said earlier that "Gospodi" implies, roughly speaking, that the speaker sees God as the Lord of the universe. I can now say more precisely that this vocative expresses an attitude which - using NSM - can be spelled out like this:

[A] Gospodi, ... (partial explication)

you are someone above all people, you are someone above everything, you can do good things for all people, you can do good things for us

To speak roughly again, we could say that in the word "Gospodi", God is conceptualised as a supreme power in the universe who is our ultimate benefactor and protector. This interpretation of the meaning of "Gospodi" is corroborated by the data from the Russian National Corpus, where by far the most common collocation including "Gospodi" is "Gospodi, pomiluj", that is, "Gospodi, have mercy". (After "Gospodi pomiluj", the most frequent collocations are with the verbs meaning "forgive", "help", "save", "bless" and "give".)

But while such collocations support the hypothesis that the word "Gospodi" projects the image of God as a supreme protector and benefactor of people in general and "us" in particular, complex labels like "power", "benefactor" and "protector" are neither precise nor cross-translatable, so they do not provide a reliable basis for cross-linguistic comparison. By contrast, formulae like [A] are fully cross-translatable. At the same time, the use of such formulae allows us to 
capture differences between different European languages with greater clarity and precision.

Consider, for example, the Polish translation of Anna Karenina, where the word "Gospodi" in Levin's appeals to God has been systematically replaced with the word "Boże", that is, "God" in the vocative case. So in the Polish translation, Levin prays to God without constantly framing God as someone, so to speak, powerful and potentially benevolent, someone in whose hands he feels himself to be and whom he can ask for mercy. At the same time, this Polish vocative "Boże" does include one semantic component absent from "Gospodi,", as from words meaning simply "God' such as "Bog" in Russian and "God" in English.

Roughly speaking, "Boże,..." is not just a plain invocation to God, like the English "God,...", but a loving invocation. Using NSM, we can portray this loving attitude more precisely, as "I feel something very good towards you". Thus, in Polish, Levin addresses God, five times, lovingly, as "Boże". In Russian, Levin's attitude to God, expressed five times with the word "Gospodi", is different: the word itself sounds like an appeal for mercy.

I hasten to add that Russian, too, has a "loving" way of addressing God in the word "Bože", as in Boris Pasternak's wonderful autobiographical poem "V bol'nice" ('In Hospital', 1962):

(3)

'O, Gospodi, kak soveršenny

Dela Tvoi," - dumal bol'noj, -

Posteli i ljudi i steny,

Noč' smerti i gorod nočnoj.'

Ja prinjal snotvornuju dozu

I plaču, platok terebja

$\mathrm{O}$, Bože, volnenija slëzy

Mešajut mne videt' Tebja.

'O Lord', the patient was thinking, 'how perfect are Your works: the beds, and the people, and the walls, my death-night and the city at night.

I have taken a sleeping draught and I weep as I pluck at my handkerchief.

O God, tears of emotion prevent me from seeing You. (Translated by Dimitri Obolensky 1962)

So Russian has the same linguistic resources for addressing God lovingly as Polish: both languages have a loving vocative "Boże" in Polish and "Bože" in Russian. At the same time, however, Russian has another resource, which encourages Russian speakers to address God as if throwing oneself at God's mercy, in the widely used word "Gospodi". This is a uniquely Russian way of addressing God, and we have seen its importance for Russian culture in the scene from Anna Karenina.

Another example which I will adduce here comes from a recent biography of Tolstoy by Pavel Basinskij (2011), entitled Begstvo iz raja ("Running away from the paradise"). Shortly before the eighty-two-year-old Tolstoy ran away from home 
and died at a railway station, he nearly died at home, in the presence of his wife Sofia Andreevna. As Basinskij (2011, p. 29) describes that scene,

(4)

Sofia Andreevna made a terribly pitiful impression. She was raising her eyes, quickly making signs of the cross, and whispering: "Gospodi! Just not this time, just not this time!" (...) She was throwing herself on her knees next to his bed, she was praying passionately, approximately like this: "Gospodi! save me, forgive me, Gospodi, don't let him die, it was me who brought him to this, just not this time, don't take him away, Gospodi, from me.” (Basinskij 2011, my translation)

I have tried to capture this distinctive semantic profile of "Gospodi,..." in explication [B]:

[B] Gospodi... (normally used to address God, not Jesus, except in Gospel
translations; *Gospodi Iisuse,...; not possible with "moj" ('my'); exclamatory)

a) I feel something at this moment, because of this, I can't not say something to you at this moment

b) I think about you like this: "you are someone above all people, you are someone above everything"

c) at the same time I think about you like this:

"you are good, you can do good things for all people, you can do good things for us"

d) when I think like this, I feel something because of this

When one contemplates the unique semantics of the word "Gospod", and especially, of the vocative "Gospodi, ...", it is hard not to think that it reflects ages of Russian collective memory and experience linked with the image of a Godlike Tsar. Discussing in particular Russia's nineteenth-century, Russian historian Catherine Merridale sums up its main characteristics as follows:

Religion - Orthodox Christianity - was one, and autocracy, the absolute rule of the czar, another. (...) The czar ruled by divine right, and the distance that separated him from God was scarcely wider than the gulf that divided ordinary people from their monarch." (Catherine Merridale 2000, p. 22)

The idea of divinely ordained autocracy was linked with an image of the Tsar as the nation's omnipotent father and protector. This applied in particular to Russian peasants, who constituted at that time around ninety percent of the population.

Speaking of "the [Russian] peasants' religious universe" (p. 29), of the high mortality, of famines and natural disasters, of the endless suffering and precariousness of life, Merridale says that the Russian peasants' beliefs "were a matter of piety, for almost everyone believed in God, and they were focussed on self-evident commonsense, providing insurance against disaster; they were also the only means available of predicting the outcome of sowing or a harvest, both of which were, naturally, in God's hands." (p. 36) It could be suggested then, that while the Tsar in the popular image was God-like, God in the popular image was Tsar-like. 
As the Russian Orthodox philosopher Nikolaj Berdyaev wrote in his book The Russian Idea, the Russian religion - Orthodoxy — "is linked with a distinctive significance and importance attached to the Russian Tsar." (1947: 9). "The Tsar was regarded as the vice regent of God upon earth" (p. 9); and at the same time, "The image of Christ, the image of God, was overwhelmed by the image of the earthly power and to the mind of the people took on a form analogous to it." (1947: 7).

It should be clear by now that "Gospodi,..." is really very different from the English "Lord,...", which the Oxford English-Russian Dictionary glosses as "Gospodi,...".

To show how the attitude encoded in "Gospodi,..." differs from that encoded in the English word "Lord", I will note, first of all, that "Lord" is often used to address Jesus, as well as God, whereas in Russian "Gospodi,..." is normally used only to address God. So for example, when one wants to render the English phrase "Lord Jesus" in Russian, as one translator put it, "one is stuck".

According to a Google search, a song starting with the words "Come, Lord Jesus" is the most commonly sung congregational song in the United States; and a prayer starting with the words "Come quickly Lord Jesus" is a very popular prayer. But one cannot use "Gospodi,..." in this way in Russia.

Thus, the English "Lord,..." does not imply supreme power, as "Gospodi,..." does. It would not be justified, therefore, to ascribe to "Lord,..." the components "you are above all people, you are above everything". Nor is there any justification for interpreting "Lord,..." as the ultimate benefactor of humanity ("You can do good things for all people"). Finally, "Lord,..." doesn't have the exclamatory character that "Gospodi,..." has. In the explications, this last difference is captured in the contrast between "I want to say something to you now" (in "Lord,...") and "I feel something at this moment, because of this, I can't not say something to you at this moment" in "Gospodi,...". All these considerations lead me to the following explication of "Lord,...":

\section{[C] Lord,...}
a) I want to say something to you now
b) I think about you like this: "you are someone above people, you are someone above us"
c) at the same time, I think about you like this: "you are good"
d) when I think like this, I feel something because of this

There is no "you are someone above everything" here, and no "you can do good things for all people". There is also no outburst of feeling: "I feel something at this moment, I can't not say something to you at this moment".

Of course the feeling implied by "Lord,..." (component d) is different from that implied by "Gospodi,..." because it is based on a different set of thoughts ((b) and (c)): perhaps less "awed", and less "self-effacing" than that conveyed by "Gospodi,...". Metaphorically speaking, if "Lord,..." implies a sustained kneeling 
position, "Gospodi,..." implies "throwing oneself on one's knees", as in the passage about Tolstoi's wife.

In this context, it is interesting to note that in the English translations of Father Alexandr Men's prayers the word "Lord!" sometimes appears at the beginning of a prayer, on a separate line, and is supplied with an exclamation mark. This looks odd in English, and this odd effect highlights the differences between "Gospodi!" and "Lord,...". The most obvious difference is the exclamatory character of "Gospodi!", reflected in the exclamation mark, and accounted for in the first line of the explication, which sounds like an emotional outburst and at the same time, an irresistible urge to turn to God: "I feel something at this moment, because of this I can't not say something to you at this moment".

\section{French: Addressing God with "mon Dieu"}

Judging by French literature, the most common way of addressing God in French in personal prayer is doing so with the phrase "mon Dieu" (literally, "my God'). The phrase "mon Dieu" is also used in French as a common everyday expression of quiet and reflective emotion, very different in meaning from the English exclamatory expression My God!

Reflecting on the use of "mon Dieu" as a way of addressing God, I will note, first of all, that it is extremely common, not only in prayer as such, but also in meditation, in diaries, in journals, and in other similar genres. For example, in Charles Peguy's work Le Mystère de la charité de Jeanne d'Arc (1910) this phrase often occurs several times per page, in Jeanne D'Arc's interior monologues. Here is one example, a passage in which this phrase occurs five times in the space of fourteen lines:

(5)

Mon Dieu, mon Dieu, qu'est-ce qu'il y a donc? (...) Qu'est-ce qu'il y a, mon Dieu, qu'est-ce qu'il y a. Il y en avait encore qui se sauvaient. Il y en avait qui en réchappaient. Mais maintenant, mon Dieu, qui répondrait qu'il y en a qui se sauvent. (...) Qu'est-ce qu'il y a donc, mon Dieu, qu'est-ce qu'il y a donc de changé, qu'est-ce qu'il y a donc de nouveau.

In the English translation of the work by the bilingual French-English writer Julien Green, all these instances of "mon Dieu,..." have been replaced with the word "Lord,...":

(6)

Lord, Lord, what is the matter? At all times, alas, at all times people have lost their souls; but for the last forty years alas they have done nothing but that, they have done nothing but lose their souls. What is the matter, Lord, what is the matter. There were still some who saved their souls. There were some who came through. But now, Lord, who could be sure that some are saved, who could be sure that just a few, even just a few, even the smallest possible number, come through. It used to be in the world, alas, sometimes, often it was the world that made one ready for hell. Nowadays even that is no 
longer true; it is no longer the world that makes one ready for hell. It is hell itself overflowing on earth. What is the matter, Lord, what is it that has changed, what is there that's new. (Translated by Julien Green)

As the French extract above illustrates, the phrase "mon Dieu,..." can occur in French not only sentence-initially, as "My God,..." tends to be used in English, but also in the middle of a sentence, between clauses. In fact, it can also be used in the middle of a clause, as in the following example:

(7)

Quel peuple mon Dieu ne se fût estimé heureux (...) d'être votre peuple ; (..) peuple élu (...) (p. 67)

'What people, Lord, would not have deemed itself happy, what people among so many people, what people, among countless people, in being your people; (...) a chosen people.' (Green, p. 63)

Naturally, the question arises: why did an experienced translator and eminent bilingual writer like Julien Green feel that he had to render "mon Dieu,..." in English as "Lord,..." rather than with the seemingly closer "my God,..."? Fortunately, we have an answer to this question from Julien Green himself, for in the Preface to his translation of Péguy's work he says: "Where Péguy writes "mon Dieu," and he writes it often, I have written "Lord." Somehow it sounds nearer to "Mon Dieu" than "My God." And quieter."

This is an invaluable comment. The first point is that to Green's ear, with his perfect French-English pitch, "My God,..." sounds "louder" than "Mon Dieu,...". (I am keeping here Green's capitals, because in English, "My God,..." does tend to occur sentence-initially.) Where does this impression of "loudness" of "My God,...", as compared with "mon Dieu,..." come from, semantically?

In this paper, I argue that in English, both "God,..." and "My God,..." sound somewhat dramatic because they include the component "I want to say something to you at this moment". "Mon Dieu,..." sounds "quieter" and "less urgent" because its first component is "I want to say something to you now" — not "at this moment" but "now".

The English "Lord,..." also implies "now", not "at this moment", and so it sounds "quieter" than "My God". Another similarity between "mon Dieu,..." and "Lord,..." is that they both can occur parenthetically, in the middle of a sentence, whereas "My God,..." usually occurs at the beginning of a sentence.

In the explications, I portray the parenthetical use with the component: "I'm saying this to you now", whereas the sentence-initial use is portrayed with "I want to say something to you now".

So there are two clear similarities between "Mon Dieu,..." and "Lord,...": the quiet "now" instead of a dramatic "at this moment", and the parenthetical use: "I'm saying this to you now".

But in other respects, "Lord,..." is quite different from "Mon Dieu,..." and much closer to the French "Seigneur,...". I will mention two key differences between "Mon Dieu" and "Lord": first, "mon Dieu,..." implies a personal 
relationship with God, which "Lord,..." and "Seigneur,..." do not imply. And second, "Lord,..." (like "Seigneur,...") can be addressed to Jesus, as well as to God, whereas "mon Dieu,..." is normally not used to address Jesus.

All these differences, as well as similarities, are set out in explications [D] and $[\mathrm{E}]$.

\section{[D] Mon Dieu,...; mon Dieu,...}

a) I want to say something to you now/l'm saying this to you

b) I think about you like this: "you are God (m)"

c) at the same time, I think about you like this:

"I know you, I feel something very good towards you

you know me, you feel something very good towards me"

[E] Lord,... (= Seigneur,...)

a) I want to say something to you now/l'm saying this to you

b) I think about you like this: "you are someone above people, you are someone above us"

c) at the same time, I think about you like this: "you are good"

d) when I think like this, I feel something because of this

When one compares these two explications, one can see that they are really quite different. Component (c) of "mon Dieu,..." shows a personal bond with God, a bond of, roughly speaking, a loving trust, whereas (b) and (c) in "Lord,..." indicate a presumed bond of a community of believers with either God or Jesus.

One last point on French. In the explication of "Lord,..." I presented "Lord,..." as identical in meaning with the French "Seigneur,...". This equation of "Lord,..." and "Seigneur,..." needs a qualification. The point is that in French, addressing God requires a choice between the "intimate" pronoun "tu" and the "non-intimate" pronoun "vous", whereas in modern English speakers have no such choice and are virtually forced to use "you", which is neither "intimate" nor "non-intimate". When the French speaker addresses God as "Seigneur, tu..." this creates an impression of "intimacy" which cannot be achieved with the English speaker's "Lord, you...". Conversely, when the French speaker chooses to address God as "Seigneur, vous...", this creates a "distance" far greater than that implied by the English "Lord, you...".

The history of the choice between "tu" and "vous" to address God is a fascinating topic which deserves detailed investigation. Here, I can only say that for a long time, Catholics - that is, the great majority of French Christians addressed God with the "non-intimate" pronoun "vous", and that "the use of 'tu' was typical of French Protestants, who were often referred to, disapprovingly, as "les tutoyeurs de Dieu". As Whelan (2007: 155) put it, "they thought themselves as on familiar terms with the Almighty". The irony here is that outside France, most of Europe used the "familiar" or "intimate" pronoun to address God, and that it was mainly, speakers of French who addressed God with the non-intimate pronoun. During the twentieth-century, however, this changed, and in present-day French, 
God is normally addressed as "tu", whether in combination with "Dieu" or "Seigneur".

I will illustrate this with an extract from a little book on prayer by the famous French cardinal and archbishop of Paris, Jean-Marie Lustiger, one in the original French, and the other, in its published English translation:

\section{(8) French original}

«Seigneur, ta volonté sur moi n'est pas comme celle d'un supérieur humain. Si par exemple je travaille, je dois me conformer à ce que m'a prescrit celui qui me donne mon travail : "Tu vas faire ceci. Il faut que tu t'occupes de cela." Ta volonté sur moi, Seigneur, est toute différente. Elle n'est pas un ordre que je ne comprends pas. Car tu me donnes ton Esprit Saint qui me fait comprendre de l'intérieur, aimer et vouloir ta volonté. En me confiant ta volonté, Seigneur, tu engages ta responsabilité. Car tu prends ta responsabilité à mon égard, beaucoup plus que mon père ou ma mère ne l'ont prise en mettant un enfant au monde. Tu ne m'as pas seulement voulu pour que je sois enfanté à la vie, tu ne m'as pas seulement donné la joie d'exister (je dis bien: la joie d'exister, même quand notre existence est douloureuse et difficile). En me créant, tu as pris le risque de ma liberté et tu ne cesses de me vouloir. Ta volonté n'est pas une fatalité qui s'impose à moi : elle est la condition de ma liberté.

En retour, Seigneur, je veux t'en rendre grâce et prendre ma responsabilité envers toi qui as pris ta responsabilité envers moi. En te rendant compte, heure par heure, de ce que j'ai vécu, de ce que j'ai fait, je veux, à mon tour, être responsable devant toi qui te fais responsable de moi. Ce n'est pas vers moimême que je me tourne, mais vers toi, Seigneur, qui sans cesse m'habites et me donnes de vivre. » (Lustiger 1986, pp. 115-116)

\section{(9) English translation}

Lord, Your will for me, I know, is not like that of a human superior. When I go to work, I have to follow the orders of whoever hired me: "Do it this way. Get busy on that." Your will for me, Lord, is altogether different. It is not like an order that I don't understand, because You give me Your Holy Spirit, who guides me to an interior understanding and teaches me to love You and desire Your will for my life. In confiding Your will to me, You once again engage Your responsibility. You have already taken on a responsibility for me, much more than my mother and father took in bringing me into the world. You have not only willed that I be born, and given me the joy of living (I repeat, the joy of living, even when life is painful and difficult), but in creating me You took the risk of entrusting me with the freedom to respond to or ignore. Your unceasing call. I realize, Lord, that Your will is not a fatality which is imposed on me: it is rather the condition of my freedom. (pp. 89-90)

In return, Lord, I want to thank You for my freedom and assume my responsibility towards You who have assumed such a great responsibility towards me. I am going to do that by giving You an hour-by-hour account of how I spent my day. It is not towards myself that I turn, but towards You, Lord, who are always with me and sustain my life. (translated by Rebecca Howell Balinski, 1997) 
Although the meaning of the word Seigneur is either identical or almost identical to that of Lord, the overall impression created by each passage (the French and the English one) is different. The reason is that a combination of Seigneur with the intimate pronouns "toi" and "tu" appears to create a sense of, roughly speaking, intimacy, which is absent from the English text, where "Lord" is combined with the neutral pronoun "you".

Apparently, for many English speakers today who want to speak to God, one major way to compensate for the sense of distance projected by the English invocation "Lord + you" (and also, "God + you") is to introduce the adjective "dear", and to address God as "Dear God" or "Dear Lord" - options which have no parallels in French (normally one doesn't address God in French as "chér Dieu" or "chér Seigneur"). I will return to this in section 6 (on English).

To conclude the discussion of "mon Dieu", I will note that what is particularly striking about this expression from a comparative perspective, is its combination of a calm conversational tone with a deep devotion and trust. It is not anchored in feeling, as "Gospodi!" and it is not dramatic like "My God", which is linked with a momentary impulse. The calm conversational tone of "mon Dieu" may bring to mind the English expression "Dear God," but as we will see later, "Dear God" doesn't imply a deep personal relationship with God, which is present in "mon Dieu" and its English "literal" counterpart "My God". It seems distinctly French as intuited by Julien Green.

\section{German: addressing God as "Herr"}

The most distinct German way of addressing God is, I believe, "Herr". As I will illustrate very shortly, "Gott,..." and "mein Gott" are also used, but these appear to have their semantic counterparts in the English terms "God,..." and "my God, ..." (except that in English, it is usually "O God" rather than "God"). On the other hand, "Herr,..." is, as I will argue, uniquely German.

In his prison cell in Tegel in 1943 Dietrich Bonhoeffer wrote a number of prayers for his fellow prisoners. Here are three extracts, first in German and then in an English translation by Reginald Fuller.

(10) Morgengebet

Gott, zu dir rufe ich am frühen Morgen

Hilf mir beten und meine Gedanken sammeln; ich kann es nicht allein.

\section{Morning prayers}

O God, early in the morning I cry to thee, Help me to pray and to concentrate my thoughts on thee I cannot do this alone.

\section{(11) Abendgebet}

\section{Herr mein Gott,}

ich danke dir, daß du diesen Tag zu Ende gebracht hast.

ich danke dir, daß du Leib und Seele zur Ruhe kommen läßt

Deine Hand war über mir und hat mich behütet und bewahrt. 
(...)

Ich befehle dir die Meinen, ich befehle dir dieses Haus, ich befehle dir meinen Leib und meine Seele

Gott, dein heiliger Name sei gelobt.

Amen.

\section{Evening prayers}

O Lord my God, I thank thee that thou has brought this day to a close; (...) Into thy hands I commend my loved ones and all who dwell in this house; I commend to thee my body and soul. O God, thy holy name by praised. Amen.

\section{(12) Gebet in besonderer Not}

\section{Herr Gott,}

großes Elend ist über mich gekommen.

Meine Sorgen wollen mich erdrücken

ich weiß nicht ein noch aus.

Gott, sei gnädig und hilf.

Gib Kraft zu tragen, was du schickst.

laß die Furcht nicht über mich herrschen.

sorge du väterlich für die Meinen,

besonders für Frau und Kinder,

schütze sie mit deiner starken Hand

vor allem Übel und vor aller Gefahr.

(...)

Ob ich lebe oder sterbe,

ich bin bei dir und du bist bei mir, mein Gott.

Herr ich warte auf dein Heil und auf dein Reich.

Amen

\section{Prayers in time of distress \\ O Lord God,}

great distress has come upon me;

my cares threaten to crush me

and I do not know what to do.

O God, be gracious to me and help me.

Give me strength to bear what thou dost send,

and do not let fear rule over me;

Take a father's care of my wife and children.

(...)

Whether I live or die, I am with thee and thou, my God, art with me.

Lord, I wait for thy salvation and for thy kingdom.

Amen

(First published in English in 1957, SCM Press 1967)

As we can see examining Bonhoeffer's prison prayers, he addresses God as "Gott" (twice), "mein Gott" (once) and "Herr", four times. In addition, there are 
also the combinations of "Herr" and "Gott", "Herr mein Gott," and "Herr Gott,". Judging by other collections of modern German prayers, by far the most common way of addressing God in modern German prayers is the word "Herr". For example, in a beautiful set of Lenten prayers called "Fastensäule", distributed by the Deutscher Katecheten-Verein in 1993, there are ten invocations to God, all of them, "Herr", and with two exceptions all in huge capital letters (there is also one invocation to Jesus, namely "HERR Jesus Christus").

At first sight, this ubiquitous "HERR" may seem to be a semantic equivalent of the Russian "Gospodi", but in fact it is not. First, like "Lord" in English, "Herr" can be addressed to Jesus, as illustrated by the phrase "Herr Jesus Christus" in the Fastensäule collection, and "Herr Jesus,..." is perfectly possible, whereas as we have seen, "Gospodi Iisuse,..." is not. In this respect, then, the German "Herr" is closer to the English "Lord", the French "Seigneur", the Italian "Signore" and the Polish "Pan" - all these words are equally applicable to Jesus as to God.

In one respect, however, the German "Herr" is different from all its other counterparts in Europe. Or so I argue: according to my analysis, "Herr" includes also a component of something like willing submission to authority. I will develop my argument in support of this claim in stages, focussing, for the sake of simplicity, on the differences between German and English.

The most obvious difference between the German "Herr" and the English "Lord" is that "Herr" is also addressed to people, a bit like "Mister" (Mr) and especially "Sir" is addressed to men in English. Obviously, "social titles" like "Mr" and "Sir" cannot be addressed to God. By contrast, "Herr" is addressed both to God and to men, and the two meanings are felt to be closely related.

I have published two papers on the meaning and use of "Herr" as used to address men. The main conclusion reached in those papers was that "Herr" as used to address people (men) includes in its meaning a component of something like submission to authority, which is absent from "Frau" (the counterpart of "Herr" used to address women). This may or may not apply to "Herr" combined with a surname, but it does apply, I argued, to "Herr" without the surname, in combinations with titles implying rank. I have represented this component as follows:

Herr Direktor, Herr Hauptmann, Herr Oberleutnant, etc.

I think about you like this:

"you are someone above many people

If you want these people to do something, they can't not do it"

I will argue that this component (albeit in a modified form) carries over to "Herr" as a term used to address God, or Jesus. Before we move to that, however, let me point out that German dictionaries recognize some such components in the meaning of "Herr" when used without a surname.

For example, the Academy dictionary Wörterbuch der Deutschen Gegenwartssprache (1973) singles out a distinct use of Herr which it links with 
shop assistants and tradesmen and illustrates with one sentence given without a source and one from Heinrich Böll's novel Billard um halbzehn (1961):

(13)

Was darf es sein, mein Herr?

('What should it be, my Herr?')

Auch die Kartoffeln, der Herr - und vielleicht etwas Salat?

('The potatoes, too, sir — and perhaps a little lettuce?'), (p. 172)

Langenscheidts Standard German-English Dictionary (1983) glosses the word Herr used as a form of address ("Anrede") as "Sir". It also glosses the address "mein Herr" ('my Herr') as Sir. The English translation of Böll's novel (Billiards at half past nine, Böll 1976) renders "der Herr" in the sentence above as "Sir", and in some respects such uses are indeed comparable to the use of "Sir" (and "Madam") in service encounters in present-day English, although "Sir" could never be combined in such encounters with "my" (*my Sir).

For example, when a (male) taxi driver addresses a customer as "Sir", he places himself, as it were, at the customer's disposal ("at you service, Sir"), and indicates a willingness to follow the (paying) customer's instructions. The professed willingness to follow instructions from customers, however, does not amount to a willingness to take orders from a particular customer: the word "my" could be used by a butler speaking to his 'lordly" employer ("Yes, my Lord"), but not by a taxi driver speaking to a customer (*Yes, my sir).

But of course, in English, "Lord" is not used by taxi drivers to address their passengers, and "Sir" is not used to address God.

I will illustrate the use of "Herr" (on its own) and "mein Herr" as addressed to people with two further examples from Heinrich Böll, the first, with multiple uses of "Herr" alone, and the other, with "mein Herr". The first example comes from Böll's play "Eine Stunde Aufenthalt" (1957 in Böll 1962) where there are three interlocutors: a passenger, a porter, and a taxi driver. Both the porter and the taxi driver consistently address the passenger as "Herr" — the porter, nineteen times, and the taxi driver, five times - whereas the passenger doesn't address either of them in this way. (Träger means 'porter', and Fahrer, 'driver'. Here, the translation is mine, A.W.)

Träger: Noch nicht entschlossen, Herr? (p. 242)

'You haven't yet decided, Herr?'

Träger: Fünf Mark — zuviel, Herr? (p. 245)

'Five mark - too much, Herr?'

Fahrer: Wie Sie wünschen, Herr. (p. 248)

'As you wish, Herr.'

Fahrer: Soll ich anhalten, Herr? (p. 255)

'Should I stop, Herr?

Fahrer: Wir sind da, Herr. Sieben Mark achtzig. (p. 255)

'We're here, Herr. Seven mark eighty.' 
The second example comes from Böll's Billiards at half past nine (English translation by Patrick Bowles, 1976):

--Bitte, sagte Schrella, “würden Sie mir das so einpacken lassen, daß kein Fett nach außen dringt?" (...)

--Es wird kein Fett nach außen dringen, mein Herr", sagte der Kellner, "es ist alles in Cellophan verpackt (...)" (p. 205)

--“would you please have this wrapped for me," said Schrella, "so the fat doesn't leak out? (...)

"The fat won't leak out, sir," said the waiter, “it's all wrapped in cellophane (...)". (p. 173)

There can be little doubt that the attitude conveyed by "mein Herr" in the German sentence is different from that expressed by "Sir" in the English translation. As I have argued in my two papers on "Herr" (Wierzbicka 2015, 2016b), the meaning conveyed by 'mein Herr' can be portrayed (in part) as follows:

mein Herr ('my Herr')

(...)

I think about you like this:

"this someone is someone above me

if this someone wants me to do something, I can't not do it"

I can't present all the evidence here, but I think I can say that the case for something like voluntary submission in "Herr" and "mein Herr" as used to address men is quite strong. But how do we know that the same attitude is embedded in these words as addressed to God?

Here, evidence comes above all from the company that "Herr" often keeps in German prayers, as can be illustrated with the translations of the psalms. Arguably, in all European countries, the psalms are the main school of prayer, and in all European countries, cultural attitudes to God are strongly influenced by the local translations of the psalms. German translations of the psalms are strongly influenced by Luther's Bible. The attitude to God projected by the translations of the psalms based on this tradition is quite different from that projected by the English, or French, or Polish translations.

As I argue in earlier work, German has a whole cluster of cultural keywords suggesting, roughly speaking, authoritarian attitudes and values. These words include Befehl, gehorchen, Gehorsam, Ordnung, Pflicht and dürfen. All these words reflect what German writer Bernhard Schlink (2007) calls "Ordnungsehnsucht" ('longing for Ordnung'). What is most relevant here is that some of these words play an important role in German translations of the psalms.

Since in the German translations of the psalms such as that in Die Gute Nachricht in heutigem Deutsch (1982) the word "Herr" keeps company with words like Befehl, befehlen, gehorchen and Gehorsam, it is likely that it carries the 
semantic component which those other words share, and which is also included in the meaning of "Herr" as a term of address directed at "high-ranking" men.

For example, in his translation of Psalm 119, Luther (1545) uses the noun Befehl(e) (an order or orders) and the verb befehlen (to order) as many as 16 times, whereas the King James Bible and the New King James Version do not use the words $\operatorname{order}(s)$ and to order at all, relying instead on less military-sounding words like precepts and commandments. But Modern German translations of the Bible follow Luther in relying heavily on Befehl. What is particularly striking in the modern German translations of the psalms is the frequent use of the words gehorsam 'obedient', ungehorsam 'disobedient', Gehorsam 'obedience' and gehorchen 'to obey', in contexts where obedience is not used in the English translations (although this doesn't seem to go back to Luther). For example, the verse rendered in both the King James Bible and the New King James Version as "Create in me a clean heart, O God" (Psalm 51, v. 14) appears in Die Bibel: Die Gute Nachricht in heutigem Deutsch as "gib mir ein gehorsames Herz!" ('give me an obedient heart!'). Similarly, Psalm 50 (vs. 16 and 23) contrasts two kinds of man, "the disobedient one" ("[den] Ungehorsamen") and "the one who obeys me" ("wer mir gehorcht"), whereas the King James Version and the New King James Version use instead the phrases "the wicked" and "[he] who orders his conduct aright". This contrast between the 'Puritan' concepts 'wicked', 'conduct' and 'right' and the words Gehorsam and gehorchen characteristic of the German translations is very striking.

Similarly, in Psalm 36 (v.11), the German text asks God to show goodness to those "die dir gehorchen" ("who obey you'), whereas the English text (again, in both the King James Version and the New King James Version) refers to "the upright in heart". In Psalm 50 (v.5), according to Die Bibel: Die Gute Nachricht in heutigem Deutsch, God says (using both gehorchen 'obey' and verpflichtet): "Holt mir die meinen zusammen (...). Sie haben einen Bund mit mir geschlossen und sich verpflichtet mir zu gehorchen." "...bring me my people together, (...), they have concluded a covenant with me and have taken upon themselves the Pflicht to obey me". But The King James Version and the New King James Version do not use here the word obey: "Gather my saints together unto me (NKJV: to me), those who have made a covenant with me by sacrifice."

The word "Herr" as a form of address is very prominent in the German psalms, often seemingly added in lines where the English translations don't include the word "Lord," and often accompanied by words like "befehlen" ('to order') and "gehorchen" ('to obey'). I will adduce here four examples from Psalm 119 in the German Bible (Die Bibel im heutigen Deutsch) and in the English New Revised Standard Version:

(16) Psalm 51

Verse 10

German (Die Bibel in heutigem Deutsch, henceforth DBHD, 1982)

Gib mir ein gehorsames Herz! 
English (New Revised Standard Version, henceforth NRSV, 2009)

Create in me a clean heart, O God!

German (Die Luther Bibel, henceforth LB, 1545)

Schaffe in mir, Gott, ein reines Herz (...)

(17) Psalm 31

Verse 19

German (DBHD, 1982)

Wie gross is deine Güte, Herr! Du wendest sie denen zu, die dir gehorchen.

Vor aller Augen zeigt sich diese Güte an denen die bei dir Zuflucht suchen.

English (NRSV, 2009)

O how abundant is your goodness that you have laid up for those who fear you,

and accomplish for those who take refuge in you in the sight of everyone!

German (LB, 1545)

Wie groß ist deine Güte, die du verborgen hast für die, so dich fürchten, und erzeigest vor den Leuten denen, die auf dich trauen!

English (King James Bible, henceforth KJB, 1611)

$\mathrm{O}$ how great is thy goodness, which thou hast laid up for them that fear thee; which thou hast wrought for them that trust in thee before the sons of men!

(18) Psalm 119

Verses 115-116

German (DBHD, 1982)

Ihr Unheilstiften, geh mi raus der Augen, Ich folge den Befehlen meines Gottes.

Herr, sei mein Halt, dass ich leben kann. [LB: "Gebote"]

English (NRSV, 2009)

Go away from me, evildoers, that I may keep the commandments of my God. Uphold me according to your promise, that I may live and let me not be put to shame in my hope.

\section{Verse 166}

German (DBHD, 1982)

Herr, Meine Hoffnung ist dass du mir hilfst, ich führe aus was du befohlen hast. [LB: "Gebote"]

English (NRSV, 2009)

I hope for your salvation, Lord and I fulfil your commandments.

\section{Verse 145 (146)}

German (DBHD, 1982)

Von Herzengrund schreie ich zu dir; gib Antwort!

An deine Regeln Herr will ich mir halten.

Ich rufe dich zu Hilfe, rette nich!

Ich werde deinen Weisungun gehorchen. [LB: dass ich deine Zeugnisse halte"] 
English (NRSV, 2009)

Your decrees are righteous forever: Give me understanding that I may live. With my whole heart I cry: answer me, O Lord.

I will keep your statutes.

\section{Verse 172-173}

German (DBHD, 1982)

Für mein Versprechen soll mein Mund dir singen, was du befohlen hast, ist recht und richtig.

Strecke deine Hand aus, Herr, um mir zu helfen. Ich habe mich für dein Gesetz entschieden.

[LB: "alle deine Gebote sind recht"]

\section{English (NRSV, 2009)}

My tongue will singe of your promise for all your commandments are right.

Let your hand be ready to help me, for I have chosen your precepts.

It is also worth noting that in the Bibel in heutigem Deutsch several headings have been given to various psalms which include the word "Gehorsam" ("obedience'). No such headings with "obedience" are to be found in English translations of the psalms. When a psalm starts with the word "Herr", under a heading which says "Gehorsam", this would presumably further encourage a reading of "Herr" with the component which "Herr" (as in "mein Herr" addressed to men) and "Gehorsam" share.

Thus in earlier work, I have suggested that the word "Herr" (when used without a surname) belongs to the same semantic and cultural cluster as Befehl, befehlen, Gehorsam, and gehorchen (order(s), obey, obedience), and I am now suggesting that this has some semantic repercussions for the use of Herr to address God.

To say this is not to try to somehow take away from the beauty and spiritual depth of German prayers such as the "Fastensäule", based exclusively on "Herr,..." as the way of addressing God. In the context of a full explication of "Herr," (as addressed to God) the components linking "Herr" with "Gehorsam" can be interpreted in a sense which makes "Herr" different and more akin to a heartfelt desire to do God's will. Nonetheless if the component "if you want us to do something we can't not do it" is indeed (as I argue) part of the meaning of "Herr," it needs to be acknowledged, for a better understanding of the whole complex picture.

The overall explication of "Herr," as addressed to God can, I think, look like this:

[F] Herr, ... (German)

a) I want to say something to you now

b) I think about you like this:

"you are someone above people, you are someone above us; you are good"

c) at the same time, I want to think about you like this:

"if you want us to do something, we can't not do it"

d) when I think like this, I feel something because of this 


\section{Addressing God in English: From "O God,..." to "Dear God,..."}

If we look at the English language of prayer from a broader European perspective we notice two striking idiosyncratic features: the first is the frequent presence of the vocative interjection "O" (as in "O God" and "O Lord"), and second, the use of the phrase "Dear God". I will discuss these two distinct features of English in sections 5.1 and 5.2.

\subsection{The vocative interjection "O God,...", "O Lord,..."}

The use of the phrase of "O God" is very widespread in English religious language. "O Lord" is also common, but for the sake of simplicity I will focus on "O God". Here are three examples from a collection entitled A Prayer Book for Australia (published in 1995 by the Anglican church in Australia and intended for use in churches):

Prayer of the day

O God, your Son has taught us that those who give a cup of water in his name will not lose their reward. (p. 587)

Prayer of the week

O God, you have prepared for those who love you such good things as pass our understanding. (p. 588)

Prayer of the day

O God, you are rich in love for your people: show us the treasure that endures and, when we are tempted by greed, call us back in to your service (...). (p. 585)

The use of that special vocative interjection creates the impression that the people who are praying are calling to God over a distance, and also, that they are paying homage to God, as well as addressing him. (In older English texts, someone can address a sovereign in this way (e.g. "O Queen!", "O Majesty") but not an ordinary mortal (*O John! *O Jane!). One line from a poem entitled "The Creatures of God" by the nineteenth-century English poet Frederick William Faber illustrates the rhetorical and elevated tone of the vocative interjection "o" well: "O majesty unspeakable and dread!"

How did English develop such a way of addressing God, which may imply awe and which seems to preclude intimacy?

The matter deserves detailed investigation, but it seems clear that by the time the King James Bible (1611) and the Book of Common Prayer (1662) were published, there was a well-established tradition in English of rendering the Latin and Greek vocatives with the vocative interjection "O", as "O God" and "O Lord". This is particularly striking in the case of translation of the Psalms: in the English translations, "O God" and "O Lord" predominate, whereas, for example, in Luther's 
German Bible or in the Polish sixteenth-century Psalter translated by poet Jan Kochanowski the vocative interjection was normally not added. For example, if we look at the 1662 version of the Book of Common Prayer, several psalms start with a Latin quote, without a vocative interjection, and an English translation adding it, for instance:

(22)

\section{Psalm 51}

Latin: Miserere me, Deus.

English: Have mercy upon me, O God,...

(23)

\section{Psalm 55}

Latin: Exaudi, Deus.

English: Hear my prayer, O God...

\section{Psalm 63}

Latin: Deus, Deus meus.

English: O God, thou art my God: early will I seek thee.

\section{Psalm 64}

Latin: Exaudi, Deus.

English: Hear my voice, $\mathbf{O}$ God.

There can be little doubt, however, that even though the tradition of addressing God in prayer with "O" was well established in English before the Book of Common Prayer, the popularity of this Book across the English-speaking world has contributed, perhaps in a decisive way, to the survival of that tradition up to the present time. In this connection, let me quote from the Introduction to a 2011 collection of three texts of the Book from the 16th and 17th centuries edited by Brian Cummings:

The Book of Common Prayer is one of the most extraordinary books in history. From the Reformation to the Beatles, with some interruptions and alterations, it formed the order of service in the established church in English. It has been said, with some justice, that it has reached more listeners, via its daily offices, than the works of Shakespeare. Human life in the English imagination is mediated through its idiom: in loving a partner, we promise to 'love her, comfort her, honour and keep her in sickness and in health'; in saying farewell to the dead, we come to terms with our own mortality, 'Earth to earth, ashes to ashes, dust to dust'. In the breadth of this practical influence, Prayer Book prose has seeped into the collective consciousness more profoundly than that of any other book written in English, even the Bible. Millions of Englishspeaking people, godly, wicked, or indifferent, have been baptized, married, or buried to its words. 
This "rhetorical" tradition of addressing God with "O God" continues in English to this day in many English-speaking countries, including Australia, both in public worship and in private prayer. For example, in the bilingual volume The Orthodox Prayer Book, published in 2010 in the US in English and in Church Slavonic, we find phrases like "O God", "O Lord" and "O Saviour" on almost every page (on the left side), facing (on the right hand) pages with the words "Bože", "Gospodi", and so on, without the vocative interjection. As for private prayers, here is Thomas Merton (2004), a Trappist, praying to God in his monastery in Kentucky with "O God", as well as "God", "My God" and "Lord":

O God, my God, why am I so mute? I long to cry out and out to Thee, over and over, and Thou are nameless and infinite. (p. 11)

My God, it is to you alone that I can talk because nobody else will understand.

My God, I pray better to You by breathing, I pray better to You by walking than by talking. (p. 57)

O God, my God, the night has values that the day has never dreamed of. (p. 81)

God, have mercy on me in the blindness in which I hope I am seeking You! (p. 105)

Now is the time to get up and go to the tower [for the Fire Watch, I think, A.W.] Now is the time to meet You, God, where the night is wonderful (...) (p. 83)

Lord, it is nearly midnight and I am waiting for You in the darkness and the great silence. (p. 5)

I will travel to You, Lord, through a thousand blind alleys. You want to bring me to You through stone walls. (p. 23)

To show the special "rhetorical" semantics of "O God, ..." as compared with

"God,..." and "My God,..." I propose the following explications:

\section{[G] God,...}

a) I want to say something to you at this moment

b) I think about you like this: "you are God (m)" 
[H] O God,...

a) I want to say something to you at this moment

b) I want you to hear it

c) I think about you like this: "you are God (m)"

d) when I think like this, I feel something because of this

\section{[I] My God,...}

a) I want to say something to you at this moment

b) I think about you like this: "you are God (m)"

c) at the same time I think about you like this:

"I know you, I feel something very good towards you,

you know me, you feel something very good towards me"

According to these explications, all three invocations with the word "God,..." include in their meaning the phrase "at this moment", which makes them sound like an interjection, because of the implied "urgency" of that momentariness. However, "God,..." by itself does not imply a feeling, whereas both "O God,..." and "My God,..." do. Further, "O God,..." sounds like "calling" to God. In the explication of "O God,..." this is accounted for by the component "I want you to hear it".

The explications of "God" and "My God" do not include the component "I want you to hear it", but they, too, sound "louder' than, for example, "Lord,...". In support of this contention, I will adduce here a Polish poem entitled "Hymn", by the romantic poet Julian Słowacki, together with its excellent English translation by the Australian translator Marcel Weyland (2010).

Every stanza in that poem ends with the words "Smutno mi, Boże", literally, "I'm sad, God" (with a dative for "I" and a vocative for "God"). In Weyland's translation of the poem, however, this key phrase is rendered not with the word "God", but with the word "Lord", as "Sad am I, Lord". I will include here only the first stanza, in Polish and in English.

Hymn (Polish original, by Juliusz Słowacki)

Smutno mi, Boże! — Dla mnie na zachodzie

Rozlałeś tęczę blasków promienistą:

Przede mną gasisz w lazurowej wodzie

Gwiazdę ognistą...

Choć mi tak niebo ty złocisz i morze,

Smutno mi, Boże!

Hymn (English translation by Marcel Weyland, 2010)

Sad am I, Lord... You for me, in the west, Have spread a rainbow with a radiant light, For me You quench within the azure crest

The fiery star of night,

Though You Your gold in sky and sea have poured,

Sad am I, Lord! 
I think Weyland was absolutely right in rendering "Boże,..." as "Lord,..." rather than "God,...". Although "Lord,..." doesn't mean the same as "Boże,...", it is definitely closer to it in tone than "God,...". "God,..." would be too "loud" and too "insistent" for Słowacki's melancholic poem. It would also sound devoid of feeling, which the Polish vocative "Boże,..." carries with it. "Boże,..." sounds a bit like "Dear God,..." and (in my terms) they both carry the component "I feel something good towards you".. "Lord,..." doesn't have that kind of feeling in its meaning, but it has some reference to feeling, and for this reason, too, it sounds much more plausible in this poem than "God,..." would. (I will return to this difference between "Boże,..." and "God,..." in section 6, on Polish.) As for the full meaning of "Dear God,...", I will discuss it in the next section.

\subsection{Addressing God as "Dear God,..." in modern English}

In a volume by contemporary American writer Marianne Williamson entitled "Illuminated Prayers" (1997) every prayer starts with the phrase "Dear God". A few examples:

DEAR GOD,

May the stars

Which fill the sky

fill me.

AMEN

(36)

DEAR GOD,

Please send miracles

To the war zones

of the world

AMEN

(37)

DEAR GOD,

May my gifts

begin to blossom

in a way that serves Your plan.

AMEN

DEAR GOD,

I surrender the world

to You.

\section{AMEN}

Not all prayers are as short as these, but they all appear to aim at childlike simplicity, and seek to establish a relationship with God different from that conveyed by phrases such as "O God,...". Saying "Dear God,..." the speaker uses a phrase which could be used in a personal letter to a family member, for example, 
"Dear Mum,...". The feeling implied by the phrase "Dear God,..." may be "very good" rather than simply "good", but it is a feeling "asserted", so to speak, rather than expressed spontaneously, as in "O God,...": "I say: I feel something very good towards you" rather than simply "I feel something very good towards you at this moment".

The presence of "I say:" in the meaning of "Dear God,..." goes hand in hand with the absence of "at this moment": "Dear God,..." is not a momentary outburst, rather, it is a form of address consistent with a conversational tone, and with a tone of calm reflection.

Addressing God as "Dear God,..." is very common in printed collections of prayers for children, younger and older. For example, in the The Lion Book of 1000 Prayers for Children (2012, Oxford: Lion Hudson) 220 prayers are listed in the index as beginning with "Dear God,...". For comparison, 22 start with "God,..." (as a form of address), 14 with "Lord,...", 10 with "Lord Jesus,..." and 6 with "O Lord,...”. Two examples:

\section{(39)}

Be in All that I Do

Dear God,

Be in all that I do, now and always.

Help me to Learn to Get Things Right

Dear God, my head is hurting,

Dear God, my brain is dead,

Dear God, I didn't understand a thing the teacher said.

Dear God, I'm not too clever,

Dear God, I'm not that bright,

Dear God, please help me find a way to learn to get things right.

The over-all meaning expressed in the addressing formula "Dear God,..." can be portrayed in the following explication:

\section{[J] Dear God,...}

I want to say something to you now

I want to say at the same time: "I feel something very good towards you"

I think about you like this: "you are God (m)"

at the same time, I think about you as I can think about someone if I know this someone very well

As we will see in the next section, it is not the same meaning as that is encoded in the Polish vocative "Boże", which also includes the component "I feel something very good towards you".

\section{Polish: Addressing God with "Boże" and "Panie Boże"}

In Polish, the most distinctive and most widely used way of addressing God is the word Boże, which morphologically is the regular vocative case of the word Bóg 'God'. As we have seen, in the translation of Tolstoy's Anna Karenina the vocative 
was used to render the Russian word "Gospodi" or 'Almighty God'. We have also seen the use of this word in the refrain of Juliusz Słowacki's poem "Hymn", where it was translated into English as "Lord,...".

The most distinct feature of this Polish vocative is its 'loving' character. As already mentioned, Russian has a similar vocative to address God, almost identical in form: "Bože". But in Russian this is not the most common way to address God because this role belongs to "Gospodi,...".

In this context, it is interesting to note that in a volume of John Paul II's prayers originally published in Italian and subsequently translated into English as Invitation to Prayer: Private prayers of Pope John Paul II (2002), God is frequently addressed as "God,...", in one case, several times in the same prayer. This looks odd in English, because — unlike "O God,..." or "Lord,..." — "God,..." carries no feeling component with it. Writing in Polish, John Paul II would have of course used "Boże,..." in all these cases.

It is hard not to think that in his inner speech, John Paul II was thinking with the loving Polish vocative "Boże,...". When his prayers were translated into English, however, the heartfelt "Boże,..." became a rather cold (as well as loud) "God,...". As a result, the English version doesn't sound like John Paul II at all.

Polish has three other 'loving' vocatives, all three morphologically irregular: "Jezu", "Chryste" and "synu". The first two are Latin vocatives, which became entrenched in Polish instead of the regular Polish vocatives "Jezusie" and "Chrystusie" (which sometimes occur in folk songs and laments). Both forms "Jezu" and "Chryste" are often used in religious poetry, as well as in the language of prayer. One of the earliest prayers that Polish children are taught starts with the words "O dobry Jezu, ..." (literally, "O good Jesus,..."):

O dobry Jezu, kładę się spać,

Nic mi się złego nie może stać.

Mam na obronę znak krzyża twego

W imię Ojca, i Syna, i Ducha Świętego. Amen

'O good Jesus, I'm going to bed.

Nothing bad can happen to me.

I have the sign of your cross to defend me.

In the name of the Father, and the Son, and the Holy Spirit. Amen.

But the English phrase "O good Jesus" doesn't do justice to 'O dobry Jezu", because the vocative "Jezu" is so to speak imbued with love. (In some ways, "Dear Jesus" would be close to "Jezu"). In NSM terms, it carries the semantic component "I feel something very good towards you".

The same is true of the special vocative "Chryste,...", as in the poem "O jednym z pacierzy", written in 1947, that is, in Communist era in Poland when religious poetry could not be published in literary journals: 
(42)
A ja już wierny Tobie zostanę,
O Chryste, Chryste...
Choćby wzbronili wierszy o Tobie
pięknych drukować
na klęczkach będę szeptać Ci jeszcze
wzbronione słowa.

\section{English (translated by Mary Besemeres)}

As for me, I'll stay faithful to you,

Christ, my Christ...

..

Even if printing

beautiful poems about You

were forbidden

I'd keep whispering on my knees

The forbidden words.

It is interesting to note the word "my" added by the English translator, which seeks to match the emotion expressed in Polish by the grammatical form itself.

Strictly speaking, the vocatives "Jezu" and "Chryste" are beyond the scope of the present paper. I only mention them here to give some broader context to the vocative "Boże,...", which is at the very centre of my discussion.

$[\mathrm{K}] B o \dot{z} e, \ldots$

a) I want to say something to you now

b) I think about you like this: "you are God (m)"

c) I feel something very good towards you

In addition to "Boże", however, I also need to mention, if only briefly, the word "Panie", also a vocative, from "Pan", the closet Polish counterpart of "Lord" (but also, a translation equivalent of "Mr" and of "Sir"). I have studied the word "pan", in comparison with the German "Herr", in another paper (Wierzbicka 2016b). Here, I will only say that it is a ubiquitous word in everyday Polish, because it is used both as a noun and as a second-person pronoun, and because as a pronoun it is obligatory in most interpersonal relations: whenever the intimate pronoun "ty" cannot be used, "Pan" has to be used to address a man, and its feminine counterpart, "Pani", to address a woman. When used to address God, or Jesus, therefore, "Pan" sounds more "familiar" than the English "Lord" or the French "Seigneur". As I have argued in my paper on "pan" and "Herr", it also sounds more familiar than the German "Herr".

To address a man who is an acquaintance but not a close friend one combines "Panie" with the addressee's first name, usually in a diminutive, for example, as "Panie Henryku" or "Panie Heniu". When addressed to Jesus, "Panie Jezu" doesn't sound totally different from "Panie Heniu". When one addresses God as "Panie 
Boże", that doesn't sound totally different from "Panie Adamie" (to address a man called "Adam"). They do sound different, but there is also a perceptible similarity.

So on the one hand, "Boże" and "Jezu" both encode a very good feeling towards the addressee, and on the other hand, the vocative "Panie" sounds familiar - certainly more familiar than "Lord" in English or "Seigneur" in French. As a result, the collocations "Panie Boże" and "Panie Jezu", which are common in Polish prayers, also sound both loving and familiar.

From a literary point of view, the best translation of the Psalms is undoubtedly that by the great poet, Noble Laureate, Czesław Miłosz. It is also one in which the psalms sound like authentic heartfelt personal prayers. The reason is that Miłosz's translation relies, throughout, on two homely words: the loving and simple "Boże" and the familiar, everyday "Panie".

Unfortunately (as I see it), Miłosz's translation is not the one which is used in Catholic churches in Poland during Mass. Instead, what is used is the so-called Millennium Bible - the translation which was undertaken by a group of biblical scholars for the millennium of Polish Christianity in 1966. And in the psalms of the Millennium Bible, God is addressed not with the familiar Polish word "Panie,..." but with the alien and alienating word "Jahwe,...". To be sure, the familiar Polish vocative "Boże,..." and "Panie,..." are also used, but they are interspersed with unfamiliar, distant, and foreign-sounding word "Jahwe,...".

It is true that the word "Jahwe,..." is also used in some beautiful English hymns. Judging by the English literature, however, nobody prays to God in English, in private, with the word "Jahwe". The English translations of the psalms use, as we have seen, "O God" and "O Lord" - phrases which may sound rhetorical and elevated, but not foreign.

The God addressed in the Polish millennium psalms sounds like someone very distant and very foreign. By contrast, the God addressed in Miłosz's psalms sounds like someone well-known and much-loved. This closeness to God in Miłosz's psalms seems to me to be a unique feature of this translation made possible by the combination of the poet's talent and the resources of the Polish language.

A final comment, on the address phrase "Panie Boże" - absent from the psalms but common in everyday Polish. In fact, both the nominative phrase "Pan Bóg" and the vocative phrase "Panie Boże" are part and parcel of colloquial Polish, and are often used by people who are not religious believers at all. For example, poet Julian Tuwim turns in this way to God in his poem "Nauka" ('Learning'), in which he asks to be left on earth for a second life, like a schoolchild could be left for a second year in the same form.

I do dziś mam taką szkolną trwogę:

Bóg mnie wyrwie - a stanę bez słowa!

- Panie Boże! Odpowiadać nie mogę,

Ja... wymawiam się, mnie boli głowa... 
Trudna lekcja. Nie mogłem od razu.

Lecz nauczę się... po pewnym czasie...

Proszę! Zostaw mnie na drugie życie

Jak na drugi rok w tej samej klasie.

\section{English translation (by Mary Besemeres)}

Even now I have this schoolboy fear:

God will call on me in class - and I'll be stuck for words!

Dear God! I can't answer the question yet,

I... ask to be excused, my head aches...

It's a hard lesson. I haven't learnt it yet.

But I will know the answer... eventually...

Please! Leave me here for one more life

As you'd let a child repeat a grade at school.

The effect of the phrase "Panie Boże" in Polish is very different from the use of its "literal" equivalent "Lord God,..." in English. Above all, it implies more familiarity than the phrase "Lord God,...". In English, phrases like "Lord God, heavenly king..." belong to the language of the church, to the language of the liturgy, and they certainly imply religious faith. By contrast, in Polish, "Panie Boże" doesn't belong to a special religious register and is so much part of everyday language that it can even be used, occasionally, by sceptics and non-believers arguably, more so than "Boże" used by itself.

It is worth adding that Polish has also several exclamatory expressions which include the word "Boże", for example, "O Boże!", "Boże drogi” (literally, 'dear God'), “Boże kochany” (lit. also 'dear God'), “O mój Boże!”, and so on. These are not, however, ways of addressing God but ways of expressing one's feelings. By contrast, "Boże,..." is indeed a way of addressing God.

\section{Conclusion}

Each European language offers its users a range of options for addressing God. Some of these options are shared, others appear to be unique. Among the unique ones, I would include, in particular, the Russian word "Gospodi", the French phrase "mon Dieu,...", the German word "Herr,...", the English phrase "Dear God", and the Polish word "Boże". The Russian word "Gospodi,..." construes God, so to speak, as "Almighty" and "Paternal", and as someone to whom we all need to appeal for mercy. By contrast, the German word "Herr,..." construes God (and also Christ) as someone whom one needs to, and wants to, obey. The modern English phrase "Dear God,..." appears to construe God as someone whom one doesn't need to either beseech or obey but to whom one can talk as to a friend. The French phrase "mon Dieu" appears to construe God as a conversational partner, as well as someone with whom one is in a loving relationship. The Polish word "Boże" implies a habitually loving attitude to God, without any additional components like those embedded in "Gospodi,...", "Herr,...", "mon Dieu,..." or "O God,...". 
It is hard not to think that these differences in habitual ways of addressing God are underpinned by broader historical phenomena - as we have seen most clearly in the case of "Gospodi,..." and "Herr,...". The exact nature of all these links remains to be investigated.

\section{Notes}

1) Although the Latin vocative of the word for God was identical with the nominative, a phrase like "Omnipotens Deus" was no doubt perceived as a vocative, because "Deus" and "Domine" were often used together in phrases like "Domine Deus" and "Domine Deus meus".

2) For other recent NSM-based publications in this area see Wierzbicka 2018a, b, c, and 2019. For broader recent discussions of the NSM approach to language and culture, see Gladkova and Larina 2018a, and b, Kotorova 2018, Farese 2018.

(C) Anna Wierzbicka, 2020
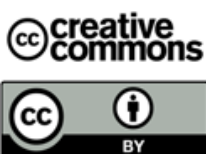

This work is licensed under a Creative Commons Attribution 4.0 International License https://creativecommons.org/licenses/by/4.0/

\section{REFERENCES}

Basinskij, Pavel. 2011. Begstvo iz raya [Escape from Paradise]. Moscow: Astrel'.

Berdyaev, Nikolaj. 1947. The Russian Idea (translated from the Russian by R.M. French). London: G. Bles, Centenary Press.

Böll, Heinrich. 1957. Eine Stunde Aufenthalt. Köln, Kiepenheuer \& Witsch.

Böll, Heinrich. 1961. Billard um halbzehn. 5.Aufl. Köln: Kiepenheuer \& Witsch.

Böll, Heinrich. 1962. Erzählungen, Hörspiele, Aufsätze. Köln, Kiepenheuer \& Witsch.

Böll, Heinrich. 1976. Billiards at half past nine, translated by Patrick Bowles. London: Calder and Boyars.

Bonhoeffer, Dietrich. 1967. Letters and papers from prison. In Eberhard Bethge (eds.), (translated by Reginald Fuller). London: S.C.M. Press.

Cummings, Brian (eds.). 2011. The Book of Common Prayer: The texts of 1549, 1559, and 1662. Oxford: Oxford University Press.

Farese, Gian Marco. 2018. The Cultural Semantics of Address Practices: A Contrastive Study between English and Italian. Lexington Books: London.

Gladkova, Anna \& Tatiana Larina. 2018a. Anna Wierzbicka, words and the world. Russian Journal of Linguistics 22 (3). 499-520. DOI: 10.22363/2312-9182-2018-22-3-499-520.

Gladkova, Anna \& Tatiana Larina. 2018b. Anna Wierzbicka, language, culture and communication. Russian Journal of Linguistics 22 (4). 717-748. DOI: 10.22363/2312-9182-2018-22-4717-748.

Goddard, Cliff. 2011 [1998]. Semantic Analysis: A practical introduction. 2nd edn. Oxford: Oxford University Press.

Goddard, Cliff. 2014. Interjections and emotion (with Special Reference to "Surprise" and “Disgust”). Emotion Review 6 (1). 53 -63. DOI: 10.1177/1754073913491843. 
Goddard, Cliff (eds.). 2018. Minimal English for a Global World. Palgrave.

Goddard, Cliff \& Anna Wierzbicka. 2014. Words and Meanings: Lexical Semantics across Domains, Languages, and Cultures. Oxford: Oxford University Press.

Goddard, Cliff \& Anna Wierzbicka (eds.). 2002. Meaning and Universal Grammar: Theory and empirical findings. 2 vols. Amsterdam: John Benjamins.

John Paul II. 2002. An Invitation to Prayer. New York. Pocket Books.

Kotorova, Elizaveta. 2018. Analysis of kinship terms using Natural Semantic Metalanguage: Anna Wierzbicka's approach. Russian Journal of Linguistics 22 (3). 701-710. DOI: 10.22363/2312-9182-2018-22-3-701-710.

Lustiger, Jean-Marie. 1986. Premiers pas dans la prière. Paris: Nouvelle Cité.

Lustiger, Jean-Marie. 1997. First steps in prayer (translated by Rebecca Howell Balinski). Glasgow: Collins, Fount Paperbacks.

Merridale, Catherine. 2000. Night of Stone: Death and memory in Russia. London: Granta.

Merton, Thomas. 2004. Dialogues with Silence: Prayers and drawings. In Jonathan Montaldo (eds.), New York: Harper Collins.

Pasternak, Boris. 1962. In hospital. In Dimitri Obolensky (eds.), The Penguin book of Russian verse: with a plain prose translation of each poem. Harmondsworth, Middlesex: Penguin.

Peeters, Bert (eds). 2006. Semantic Primes and Universal Grammar: Empirical evidence from the Romance languages. Amsterdam: John Benjamins.

Péguy, Charles. 1943 [1910]. Le Mystère de la charité de Jeanne d'Arc. New York: Pantheon.

Péguy, Charles. 1950. The Mystery of the Charity of Joan of Arc (translated by Julian Green). London: Hollis \& Carter.

Rock, Lois. 2012. The Lion Book of 1000 Prayers for Children. Oxford, England: Lion Children's Books.

Schlink, Bernhard. 2007. Vergangenheitsschuld: Beiträge zu einem deutschen Thema. Zürich: Diogenes.

Słowacki, Juliusz. 2010. Hymn. Stowo: dwieście lat poezji polskiej = The word: two hundred years of Polish poetry (translated by Marcel Weyland). Blackheath, NSW: Brandl \& Schlesinger.

Tolstoy, Lev. 1918. Anna Karenina (Translated by Louise and Aylmer Maude). Oxford: Oxford University Press.

Whelan, Ruth. 2007. From the other side of silence: Huguenot life-writing, a dialogic art of narrating the self. In Bruno Tribaut \& Ruth Whelan (eds.), Narrating the Self in Early Modern Europe, 23. 139-159. European connections. Peter Lang.

Wierzbicka, Anna. 1992. The semantics of interjections. Journal of Pragmatics 18. 159-192.

Wierzbicka, Anna. 1996. Semantics: Primes and Universals. Oxford: Oxford University Press.

Wierzbicka, Anna. 2001. What did Jesus mean? Explaining the Sermon on the Mount and the parables in simple and universal human concepts. New York: Oxford University Press. DOI: 10.1093/0195137337.001.0001.

Wierzbicka, Anna. 2003. Cross-Cultural Pragmatics. Berlin, Germany: Mouton de Gruyter.

Wierzbicka, Anna. 2014a. Imprisoned in English: The Hazards of English as a Default Language. New York: Oxford University Press.

Wierzbicka, Anna. 2014b. Can there be common knowledge without a common language? German 'Pflicht' vs English 'duty'. Common Knowledge 21(1). 141-171.

Wierzbicka, Anna. 2015. A whole cloud of culture condensed into a drop of semantics: the meaning of the German word 'Herr' as a term of address. International Journal of Language and Culture 2 (1). 1-37.

Wierzbicka, Anna. 2016a. Making sense of terms of address in European languages through the Natural Semantic Metalanguage. Intercultural Pragmatics 4. 499-527. 
Wierzbicka, Anna. 2016b. Terms of address as keys to culture and society: German Herr vs. Polish Pan. Acta Philologica [Uniwersytet Warszawski] 49. $29-44$.

Wierzbicka, Anna. 2017. W Co Wierza Chrześcijanie? Opowieść o Bogu i o Ludziach. Cracow: Znak.

Wierzbicka, Anna. 2018a. Emotions of Jesus. Russian Journal of Linguistics 22 (1). 38-53. DOI: 10.22363/2312-9182-2018-22-1-38-53.

Wierzbicka, Anna. 2018b. Polskie słowo „Boże” w perspektywie porównawczej. In Jolanta Chojak \&Zofia Zaron (eds.), Ku rzeczom niebłahym. Warsaw: Warsaw University. 221234.

Wierzbicka, Anna. 2018c. Speaking about God in universal words, thinking about God outside English. In Paul Chilton \& Monika Kopytowska (eds.), Religion, Language and the Human Mind, Oxford University Press. 19-51.

Wierzbicka, Anna. 2019. What Christians Believe: The Story of God and People in Minimal English. New York: Oxford University Press.

Williamson, Marianne. 1997. Illuminated Prayers. New York: Simon and Schuster.

\section{Dictionaries and Internet Resources}

Bonhoeffer, Dietrich (prayers compiled from online). http://www.glauben-undbekennen.de/gebete/abend-bonhoeffer.htm;

http://www.lkhb.at/redaktion/uploads/files/289e8af214a1354966e5bc7addbbd87b/d._bo nhoeffer_gebete,_gedanken.pdf; https://glaubenblog.wordpress.com/2014/12/27/gebetvon-dietrich-bonhoeffer-in-zeiten-der-not/. (Accessed 12 June 2017).

Langenscheidts Grosswoerterbuch Deutsch als Fremdsprache. 1997. Berlin: Langenscheidt. A Prayer Book for Australia. 1995. Anglican Church of Australia. General Synod.

\section{Article history:}

Received: 20 March 2020

Revised: 18 April 2020

Accepted: 20 April 2020

\section{История статьи:}

Дата поступления в редакцию: 20 марта 2020

Дата принятия к печати: 20 апреля 2020

\section{Bionote:}

ANNA WIERZBICKA is a Professor of Linguistics (Emerita) in the School of Literature, Languages, and Linguistics, Australian National University. Her work spans a number of disciplines, including anthropology, psychology, cognitive science, philosophy and religious studies as well as linguistics, and has been published in many journals across all these disciplines. She has published over twenty books, including Emotions across Languages and Cultures: Diversity and Universality (Cambridge: Cambridge University Press, 1999), English: Meaning and Culture (New York: Oxford University Press, 2006), and Imprisoned in English (New York: Oxford University Press, 2014). Her latest book, What Christians Believe: The story of God and people in Minimal English, was published by Oxford University Press, New York in 2019. Professor Wierzbicka is a Fellow of the Australian Academy of the Humanities, the Australian Academy of Social Sciences, the Russian Academy of Sciences and the Polish Academy of Arts and Sciences. She is the 
winner of the International Dobrushin Prize for 2010 and of the Polish Science Foundation's 2010 prize for the humanities and social sciences.

\section{Contact information:}

Australian National University

Canberra, ACT, 2602, Australia

e-mail: anna.wierzbicka@anu.edu.au

ORCID ID: 0000-0002-6074-7865

\section{Сведения об авторе:}

АННА ВЕЖБИЦКАЯ — известный лингвист, профессор (эмерит) Института литературы, языков и лингвистики Австралийского национального университета. Помимо лингвистики, ее научные интересы охватывают целый ряд дисциплин, включая антропологию, психологию, когнитологию, философию и религиоведение. Ею опубликовано большое количество статей в журналах по данным направлениям, а также более двадцати книг, среди которых - Emotions across Languages and Cultures: Diversity and Universality (Cambridge: Cambridge University Press, 1999), English: Meaning and Culture (New York: Oxford University Press, 2006), Imprisoned in English (New York: Oxford University Press, 2014), What Christians Believe: The Story of God and People in Minimal English (New York: Oxford University Press, 2019). Профeccop Вежбицкая является членом Австралийской академии гуманитарных наук, Австралийской академии общественных наук, Российской академии наук, Польской академии знаний, лауреатом Международной премии имени Добрушина (2010 г.) и премии Польского научного фонда (2010 г.).

Контактная информация:

Австралийский национальный университет

Canberra, ACT, 2602, Australia

e-mail: anna.wierzbicka@anu.edu.au

ORCID ID: 0000-0002-6074-7865 